\title{
Dødelighet av hjerteinfarkt i fylker og helseregioner i perioden 1951-94
}

\author{
Aage Tverdal \\ Statens helseundersøkelser, Postboks 8155 Dep, 0033 Oslo \\ Telefon $22204470(+262) \quad$ Telefax 22201673
}

\begin{abstract}
SAMMENDRAG
Basert på data fra Statistisk sentralbyrå er dødeligheten av hjerteinfarkt i fylkene studert. Dødeligheten $\mathrm{i}$ alder 40-69 år økte markert i alle fylker mellom 1951-55 og 1971-75 for deretter å avta jevnt fram til 199194. For menn er ingen av fylkene kommet ned på nivået i 1951-55, mens for kvinner er dødeligheten $\mathrm{i}$ 1991-94 lavere i fire fylker. Endringene varierte i størrelse mellom fylkene slik at rangeringen av fylkene etter dødelighet er forskjellig i første og siste periode. Det var prosentvis en svakere økning i dødeligheten for kvinner enn for menn fra 1951-55 til 1971-75 og også en svakere nedgang fra 1971-75 til 1991-94. Den nåværende tendens er meget gunstig $\mathrm{i}$ alle helseregioner.
\end{abstract}

Tverdal A. Mortality from myocardial infarction in Norwegian counties and health regions 1951-94. Nor J Epidemiol 1998; 8 (1): 79-80.

\section{ENGLISH SUMMARY}

Data from Statistics Norway on mortality from myocardial infarction in Norwegian counties have been studied. The mortality in the age group 40-69 years increased distinctly between 1951-55 and 1971-75 in all counties followed by a gradual decrease until 1991-94. For men none of the counties have yet reached the level of 1951-55, whilst for women the mortality is now lower in four of the counties. The changes varied in magnitude between the counties so that the ranking of the counties by mortality differed between the first and the last period. In per cent the increase in mortality was weaker for women than for men from 1951-55 to 1971-75, and there was also a weaker decline from 1971-75 to 1991-94 in women. The existing tendency is very favourable in all health regions.

\section{INNLEDNING}

Dødeligheten av hjerteinfarkt i alder under 70 år økte fra 1951 til omkring 1970, etterfulgt av en nedgang fram til i dag (1). Dødeligheten i siste periode var ikke nede på nivået $\mathrm{i}$ første periode. Mitt formål er å studere dødelighetsutviklingen i de enkelte fylker og helseregioner. En oppfølgingsstudie blant menn viste at kolesterol kunne forklare det meste av forskjellen i dødelighet mellom Finnmark og Sogn og Fjordane (2). Da hjerte-karundersøkelsene nå har data om kolesterol $\mathrm{i}$ to perioder for 16 fylker, vil sammenhengen mellom endringer i kolesterol og endringer i infarktdødelighet bli studert. Jeg vil videre se på om trenden i dødelighet over tid i Finnmark, Sogn og Fjordane og Oppland, hvor hjerte-karundersøkelser ble gjennomført i tre omganger, før det landsomfattende hjerte-karprogrammet tok til, adskiller seg fra resten av landet.

\section{MATERIALE OG METODE}

Antall dødsfall av hjerteinfarkt i hvert enkelt fylke, i tre ti-års aldersgrupper og ni fem-års tidsperioder, ble levert fra Statistisk sentralbyrå. Folkemengden per år i tilsvarende aldersgrupper ble også levert. Dødeligheten i alder 50-59 år for menn og 60-69 år for kvinner er tidligere publisert (3).

Hjerteinfarkt er definert ved kodene: ICD-6: 420.1 (1951-57), ICD-7: 420.1 (1958-68), ICD-8: 410-411, 412.0-412.3 (1969-85), ICD-9: 410-412, 414.0-414.3, 414.9 (1986-94).

Folkemengden etter alder i fylkene foreligger per $1.1 .50,1.1 .60,1.1 .65,1.1 .67$ og 1.1.69 deretter per 1.1 for hvert år. Personår for perioden 1951-55 ble beregnet som: $\left(\left(3^{*} 1950+1960 / 4\right) * 5\right.$, for $1956-60$ som: $((1950+3 * 1960) / 4) * 5$, for $1961-65$ som: $((1960+1965) / 2) * 5$, for $1966-70$ som: $((1967+1969) / 2) * 5$. For de etterfølgende fem-års perioder ble personår beregnet ved summen av de årlige middelfolkemengder. Dette ble gjort kjønns-, fylkesog aldersspesifikt.

Dødeligheten er estimert ved antall dødsfall dividert på personår. Standardiserte dødelighetsrater for alder 40-69 år er beregnet ved forholdet mellom observert antall og forventet antall dødsfall multiplisert med raten i standardbefolkningen. Forventet antall dødsfall er beregnet ved å anvende de alderspesifikke rater i standardbefolkningen på observasjonstiden i de tre 
aldersklasser i fylkene og Norge i tidsperiodene. Som standardrate er både benyttet dødeligheten i de tre 10års aldersklasser for Norge i 1951-55 og for Norge i hver fem-års tidsperiode. Dødeligheten i hver helseregion $\mathrm{i}$ alder 40-69 år er estimert med Poisson regresjon (4).

Standardisert mortalitets ratio for menn og kvinner samlet er beregnet som forholdet mellom summen av antall observerte dødsfall over alder og kjønn og summen av antall forventede dødsfall over alder og kjønn. Tids- og kjønnsspesifikke rater for Norge er benyttet som standard.

Følgende definisjon av helseregioner er benyttet: Helseregion 1 = Oslo, Hedmark og Oppland. Helseregion 2 = Østfold, Akershus, Buskerud, Vestfold, Telemark, Aust-Agder og Vest-Agder. Vest-Norge = Rogaland, Hordaland og Sogn og Fjordane. Midt-Norge = Møre og Romsdal, Sør-Trøndelag og Nord-Trøndelag. Nord-Norge $=$ Nordland, Troms og Finnmark.

Sammenhenger med fylket som enhet, f.eks. mellom endringer i kolesterolnivå og endringer i dødelighet, er vurdert ved å beregne Spearman korrelasjoner. Alle Spearman korrelasjonene er beregnet utfra rangeringer som går fra høyeste $($ rang $=1)$ til laveste tall. Korrelasjonskoeffisienter på 0,47 og 0,59 er signifikante på henholdsvis $5 \%$ og $1 \%$ to-sidig nivå, med 16 (18 fylker minus 2) frihetsgrader.

Gjennomsnitt for kolesterol og infarktrisk er hentet fra Wøien og medarbeidere (5).

Forholdet mellom dødelighetsrater, f.eks. mellom Oppland og Øvrige Helseregion 1 i de tre aldersklasser, er vektet sammen med Mantel-Haenszel estimatoren (6). En endring i tidsutviklingen i dette forholdet som i tid faller sammen med hjerte-karundersøkelsene, kan antyde en effekt av hjerte-karundersøkelsene. Hvorvidt det har funnet sted en slik endring er studert ved å estimere en lineær sammenheng for perioden 1951-55 til 1966-70 (1971-75) og å estimere endringen i denne sammenhengen etter denne perioden ved splines (6). Spline regresjon er også benyttet til å estimere en eventuell endring i regresjonskoeffisientene for kurvene for standardisert mortalitets ratio over tid.

Tallgrunnlaget for analysene er presentert i appendikstabellene 1a-1c.

\section{RESULTATER}

\section{Dodeligheten over tid}

Figur 1 og 2 gir aldersjusterte rater i alder 40-69 år i tre tidsperioder for menn og kvinner. I hver tidsperiode er fylkene rangert etter avtagende dødelighet. Bemerk at skalaen er forskjellig for menn og kvinner. Det er også gitt rater for Norge, både ujustert og justert $i$ forhold til Norge 1951-55.

For menn var det i Finnmark 321,9 per 100000 flere dødsfall i 1971-75 enn i 1951-55. I dette fylket var den absolutte økningen størst, mens den var lavest i Vestfold med 168,8 per 100 000. Den prosentvise økningen var størst i Sogn og Fjordane med 352\% og minst i Vestfold med $83 \%$.

For kvinner var den største og minste absolutte økningen i Troms og Aust-Agder med henholdsvis 76,0 og 15,7 per 100000 , mens den største og minste prosentvise økningen var i Nordland og Aust-Agder med $147 \%$ og $29 \%$.

Fra 1971-75 til 1991-94 inntraff blant menn den største absolutte nedgang i infarktdødelighet i Finnmark med 196,5 og den minste i Oppland med 46,5 per 100 000. Målt i prosent var ytterpunktene Nordland og Aust-Agder 147\% og 29\%.

For kvinner var differansen størst i Troms, ned 47,4 per 100 000, mens dødeligheten økte i fire fylker: Telemark, Vest-Agder, Oppland og Hedmark.

Dødeligheten i 1991-94 er høyere enn i 1951-55 i samtlige fylker for menn. Troms er lengst unna sitt utgangspunkt i 1951-55 med 192,1 per 100000 høyere dødelighet, mens Vestfold er nærmest med 11,8 per 100 000. Vestfold er også nærmest i prosent, 6\%, mens Sogn og Fjordane er fjernest, $248 \%$ over nivået $\mathrm{i}$ 1951-55.

Blant kvinnene har tre fylker lavere dødelighet $\mathrm{i}$ siste enn i første periode; Oslo, Rogaland og Vestfold. Nordland ligger høyest over sitt utgangsnivå med 44,8 per 100 000, mens i prosent ligger Oppland høyest over med $124 \%$.

\section{Fylkenes rangering etter dodelighet over tid}

Finnmark lå høyt i alle tre tidsperioder, mens Sogn og Fjordane lå lavt. Vestfold og Akershus er to fylker som over tid har flyttet seg fra en ugunstig til en gunstig rangering, mens Oppland har flyttet seg fra en gunstig posisjon og opp til landsgjennomsnittet. Spearman korrelasjon mellom rangering av fylkene etter dødelighet i 1951-55 og 1991-94 var 0,22 for menn og $-0,07$ for kvinner, som er forenlig med at det ikke er noen sammenheng mellom fylkenes plassering i første og siste periode. Spearman korrelasjon mellom menns og kvinners infarktdødelighet var 0,66 i 1951-55 og 0,79 i 1991-94. Disse sammenhenger er utover tilfeldigheter og viser at fylkene $i$ begge perioder $i$ en viss grad fulgte samme rekkefølge når de ble rangert etter menns og kvinners dødelighet.

\section{Endringer $\boldsymbol{i}$ kolesterol og endringer i dodelighet}

I 16 fylker er det gjennomført hjerte-karundersøkelser både i perioden 1985-90 og 1991-94 (5). Spearman korrelasjonen mellom prosentendring i kolesterolnivå og prosentendring i dødelighet var $-0,29$ for menn 40 49 år, $-0,05$ for menn 40-69 år og 0,16 for kvinner 4069 år. Spearman korrelasjonene mellom absolutte endringer i kolesterol og prosentvise endringer i dødelighet var av samme størrelsesorden. Korrelasjonene mellom prosentvis endring i infarktrisk og prosentvis endring i dødelighet (40-69 år) var også små; 0,06 for menn og 0,12 for kvinner. Sammenhengen mellom endringer i kolesterol og endringer i dødelighet er beskjeden og kan tilskrives tilfeldigheter. 
Figur 1. Dødelighet av hjerteinfarkt for menn, aldersjustert, i tre perioder. Fylkene er sortert etter avtakende dødelighet. Alder 40-69 år.

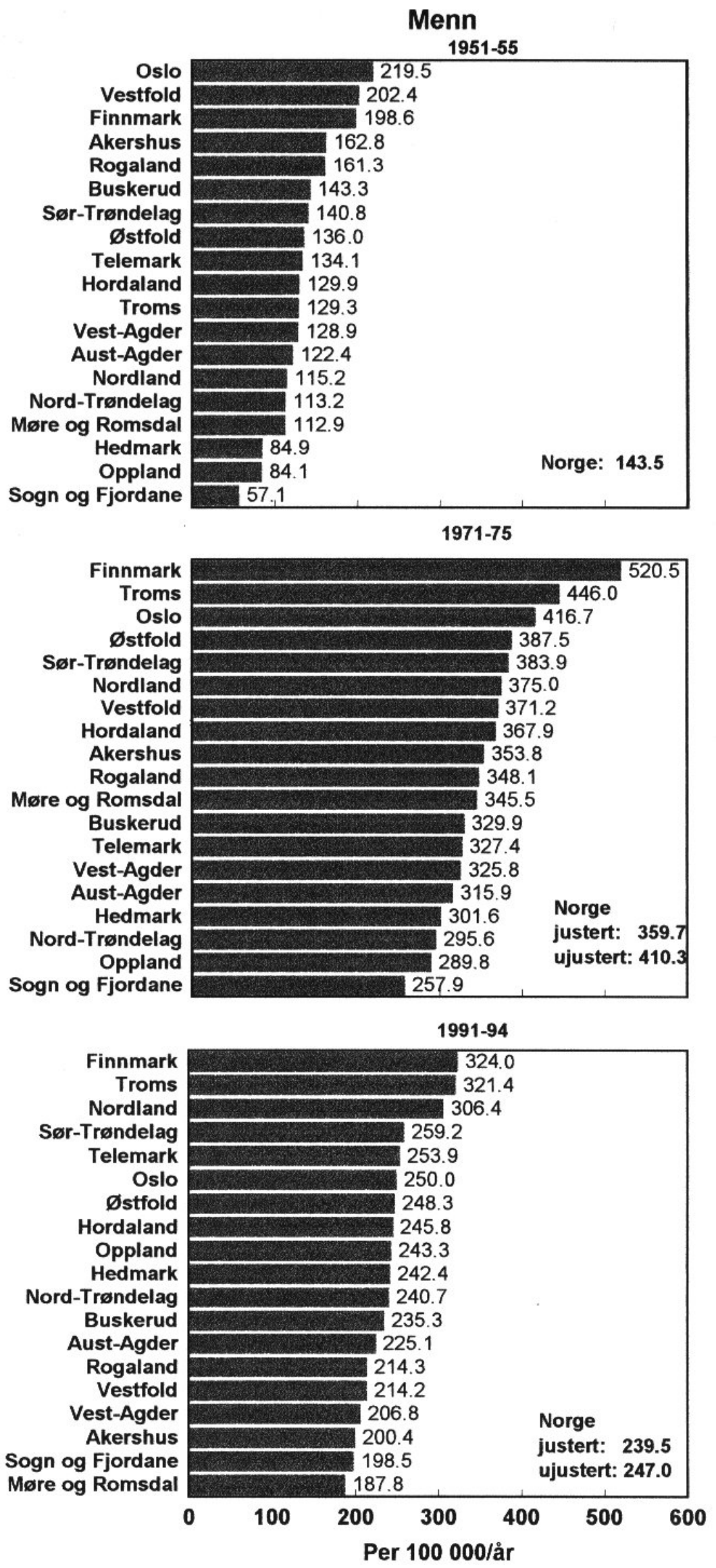


Figur 2. Dødelighet av hjerteinfarkt for kvinner, aldersjustert, i tre perioder. Fylkene er sortert etter avtakende dødelighet. Alder 40-69 år.
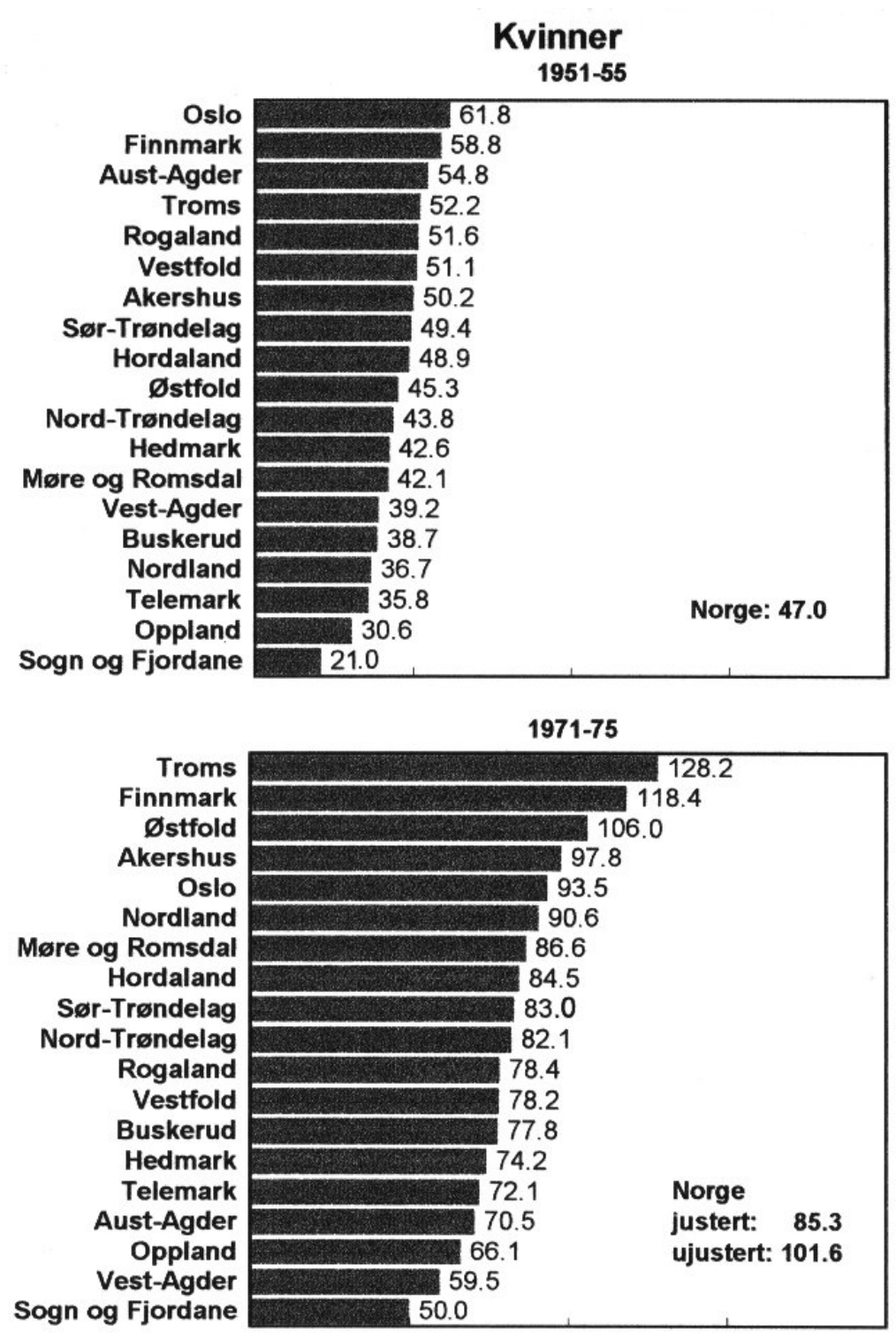

Sogn og Fjordane

1991-94

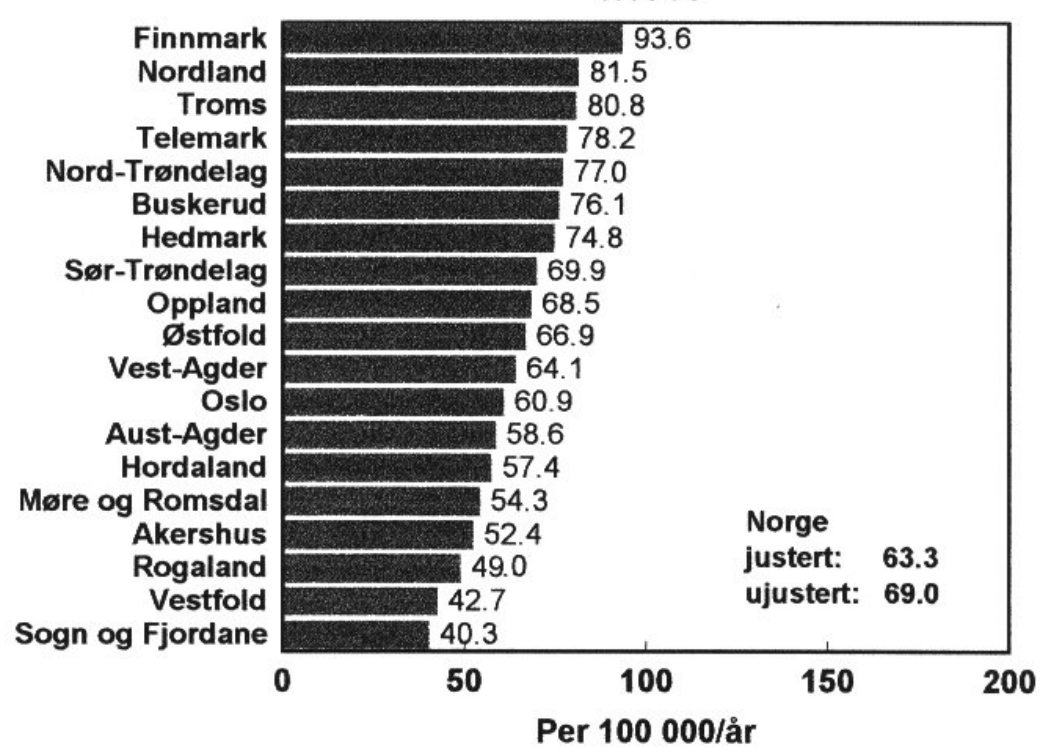




\section{Dodeligheten i helseregionene over tid}

Den relative økningen i dødelighet fra 1951-55 til 1971-75 var sterkest i Nord-Norge (tabell 1). Videre var den sterkere for menn enn for kvinner $\mathrm{i}$ alle helseregioner. Utviklingen i Helseregion 1 for menn er ganske lik den for kvinner i Nord-Norge. I NordNorge er forskjellen mellom første og siste periode større enn forskjellen mellom første og midtre periode i Helseregion 1. Det er en markert nedgang mellom nest siste og siste periode. Forskjellen var mer moderat mellom perioden hvor toppen ble nådd og nest siste periode. Det blir uhyre interessant å se om den nåværende markert gunstige tendens fortsetter.

Tabell 1. Aldersjustert dødelighet av hjerteinfarkt. Alder 40-69 år.

\begin{tabular}{lccccc}
\hline & $\begin{array}{c}\text { Helse- } \\
\text { reg. I }\end{array}$ & $\begin{array}{c}\text { Helse- } \\
\text { reg. 2 }\end{array}$ & $\begin{array}{c}\text { Vest- } \\
\text { Norge }\end{array}$ & $\begin{array}{c}\text { Midt- } \\
\text { Norge }\end{array}$ & $\begin{array}{c}\text { Nord- } \\
\text { Norge }\end{array}$ \\
\hline & & & Menn & & \\
$1951-55$ & 100 & 100 & 100 & 100 & 100 \\
$1956-60$ & 169 & 156 & 168 & 173 & 184 \\
$1961-65$ & 209 & 204 & 240 & 229 & 258 \\
$1965-70$ & 217 & 230 & 270 & 275 & 324 \\
$1971-75$ & 224 & 233 & 268 & 281 & 316 \\
$1976-80$ & 221 & 228 & 250 & 282 & 314 \\
$1981-85$ & 220 & 213 & 240 & 273 & 292 \\
$1986-90$ & 211 & 193 & 226 & 256 & 294 \\
$1991-94$ & 151 & 148 & 177 & 182 & 237 \\
& & & Kvinner & & \\
$1951-55$ & 100 & 100 & 100 & 100 & 100 \\
$1956-60$ & 143 & 147 & 157 & 136 & 161 \\
$1961-65$ & 169 & 177 & 188 & 182 & 196 \\
$1965-70$ & 174 & 203 & 179 & 192 & 223 \\
$1971-75$ & 163 & 188 & 171 & 161 & 221 \\
$1976-80$ & 174 & 168 & 174 & 161 & 221 \\
$1981-85$ & 156 & 161 & 145 & 165 & 205 \\
$1986-90$ & 167 & 160 & 143 & 166 & 211 \\
$1991-94$ & 126 & 136 & 115 & 143 & 189 \\
\hline & & & & &
\end{tabular}

\section{Utviklingen i dodelighet i Finnmark, Sogn og Fjordane og Oppland sammenlignet med utviklingen i de tilhorende helseregioner}

Dødeligheten av hjerteinfarkt i Oppland var lavere, men har over tid nærmet seg og til dels krysset dødeligheten i Øvrige Helseregion 1 (figur 3, øverste panel). På grunn av små tall for kvinner 40-49 år opereres det med bredere perioder: 1951-70, 1971-80, 1981-94. Disse perioder er valgt da de representerer oppgang, utflatning og nedgang i dødeligheten. For Sogn og Fjordane er mønsteret det samme bortsett fra for kvinner 40-49 år hvor Sogn og Fjordane lå over Øvrige Vest-Norge i de to siste av de tre utvidede tidsperioder. Dødeligheten i Finnmark har nesten hele tiden vært høyere enn i Øvrige Nord-Norge.

Figur 4 viser forholdet (ratioen) mellom dødeligheten i hvert av de tre fylker og i de øvrige fylker i den tilhørende helseregion. Ratioene i de tre 10-års aldersgrupper er vektet sammen med Mantel-Haenszel estimatoren. For Oppland var forholdet 0,46 for menn i 1951-55. Det vil si at dødeligheten i Oppland kun var
46\% av dødeligheten i Øvrige Helseregion 1 (Oslo og Hedmark). Ratioen steg til 0,97 i 1991-94, hvilket betyr at dødeligheten i Oppland og Øvrige Helseregion 1 var praktisk talt lik. For kvinner var tendensen den samme, med ratio lik $0,40 \mathrm{i}$ første og 1,05 i siste periode. Mønsteret i Sogn og Fjordane var likt det i Oppland med ratioer på 0,40 og 0,42 i første og 0,85 og 0,75 i siste periode for henholdsvis menn og kvinner. Dødeligheten i Finnmark lå hele tiden over, men nærmet seg den i Øvrige Nord-Norge (Nordland og Troms). Ratioen for menn og kvinner var 1,65 og 1,40 i første og 1,04 og 1,15 i siste periode.

Den lineære sammenhengen i de første fire perioder er ikke signifikant forskjellig fra den lineære sammenhengen i de fem siste perioder. Dette gjelder alle tre fylker og begge kjønn. Sammenligning av de fem første og de fire siste perioder ga samme resultat.

\section{Dodeligheten i Finnmark, Sogn og Fjordane og Oppland sammenlignet med Norge}

Infarktdødeligheten i Oppland har nærmet seg og såvidt passert landsgjennomsnittet (figur 5). Den lineære sammenhengen i perioden 1951-75 var ikke statistisk signifikant forskjellig fra den i perioden 1976-94. Dødeligheten i Sogn og Fjordane har nærmet seg, men ikke nådd opp til landsgjennomsnittet. Det var en sterkere stigning fram til og med 1970 enn etter 1970. Imidlertid var stigningen i periodene 1951-75 og 1976-94 ikke signifikant forskjellige. Dette gjaldt både 40-59 og 40-69 år. Finnmark har ligget høyere enn Norge i hele tidsperioden. For aldersgruppen 40-59 år har overdødeligheten variert over fem-års perioden. Det var imidlertid ingen signifikant forskjell i den lineære sammenhengen før og etter 1970, hverken for aldersgruppen 40-59 eller 40-69 år.

\section{DISKUSJON}

\section{Fylkesforskjeller}

Forholdet mellom dødeligheten i fylkene rangert på topp og bunn er blitt mindre over tid. Etter det vi vet om sammenhengen mellom kolesterol og dødelighet fra oppfølgingsstudier, inkludert hensynstagen til tilfeldige målefeil, tilsvarer forskjellen rundt $2 \mathrm{mmol} / \mathrm{l}$ 1951-55 og $1 \mathrm{mmol} / 1$ i 1991-94. Dette gjelder tilnærmet for både kvinner og menn.

I Finnmark, Sogn og Fjordane og Oppland, hvor vi har godt kjennskap til kolesterolnivået fra midten av 1970-årene, tilsvarte nedgangen i dødelighet for menn, en nedgang i kolesterol på henholdsvis $0,8,0,5$ og 0,2 mmol/l. Dette kan sammenholdes med den observerte nedgang på $0,8,0,5$ og $0,4 \mathrm{mmol} / 1$ (5).

For kvinner tilsvarte nedgangen i dødeligheten en forventet nedgang i kolesterol på 0,3 og $0,2 \mathrm{mmol} / \mathrm{l}$ i Finnmark og Sogn og Fjordane, mens det i Oppland var en forventet økning på $0,05 \mathrm{mmol} / 1$. Nedgangen var 0,9 i Finnmark, 0,8 i Sogn og Fjordane og 0,5 $\mathrm{mmol} / \mathrm{l}$ i Oppland (5). 
Figur 3. Dødelighet av hjerteinfarkt. Tykk strek er fylket, tynn strek øvrige fylker i helseregionen.

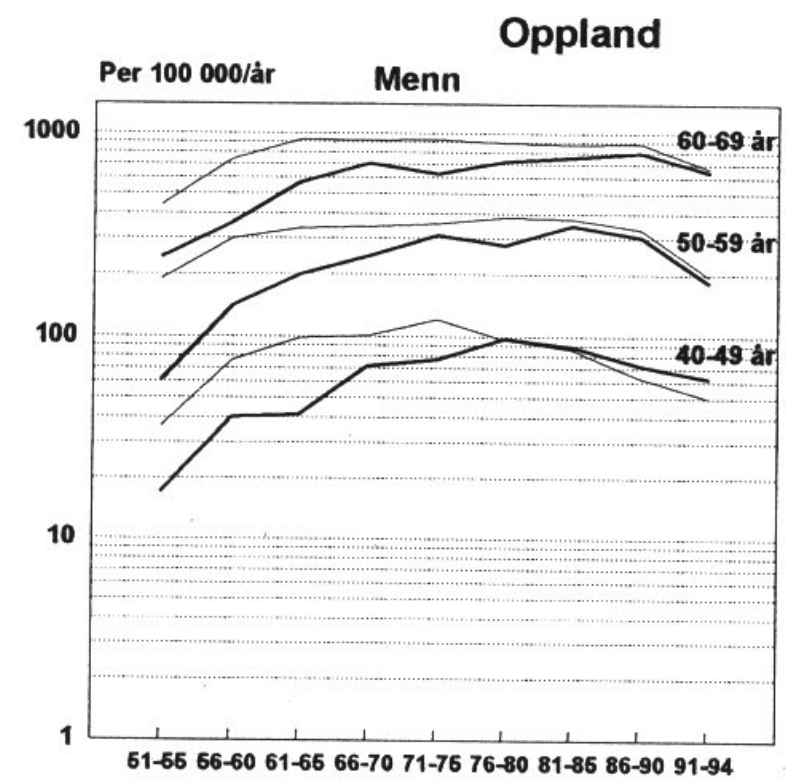

\section{Sogn og Fj.}

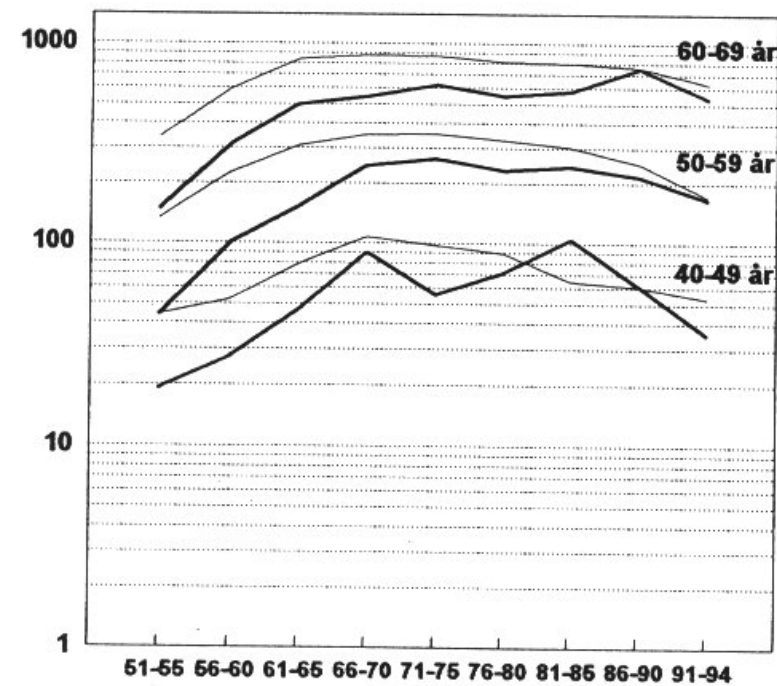

Finnmark

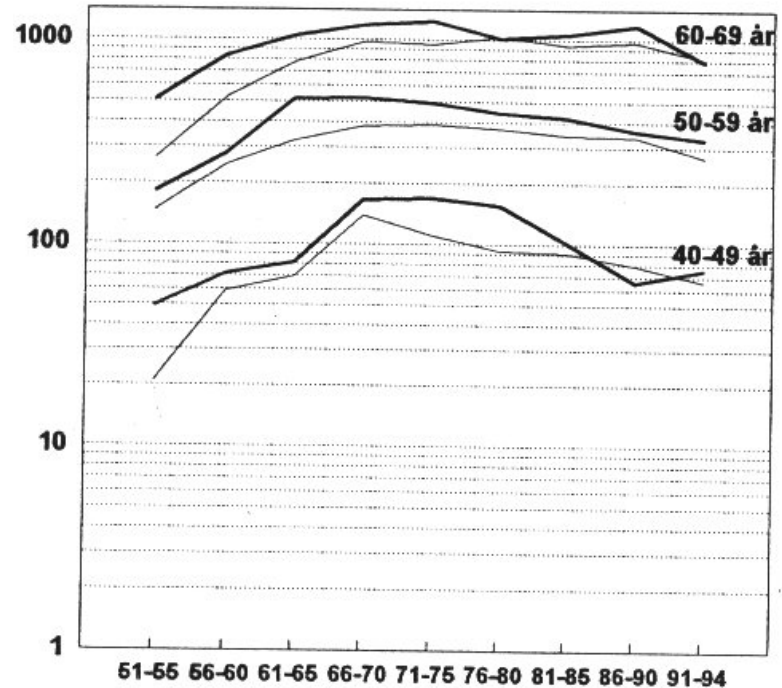

Øvrige helseregion I

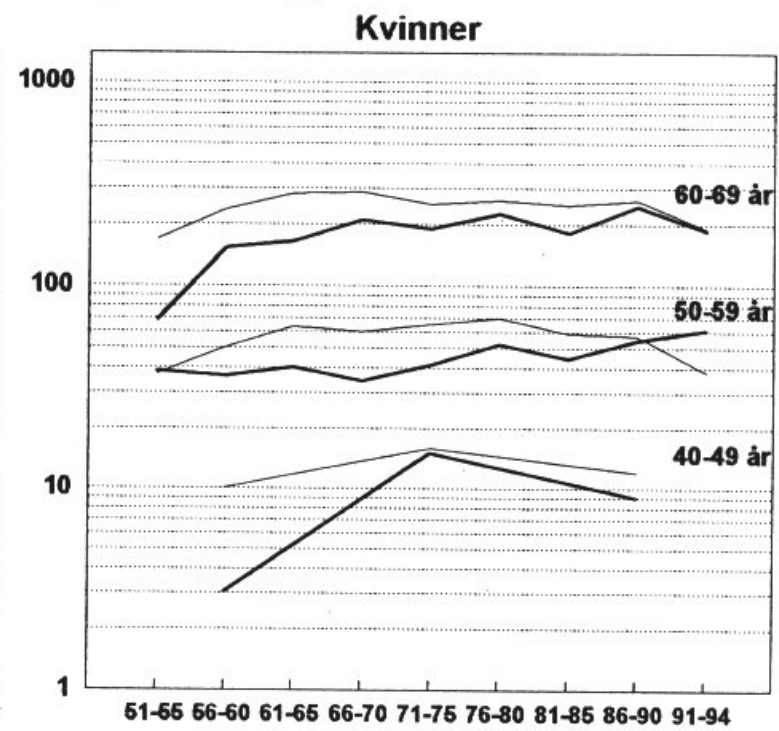

Øvrige Vest-Norge

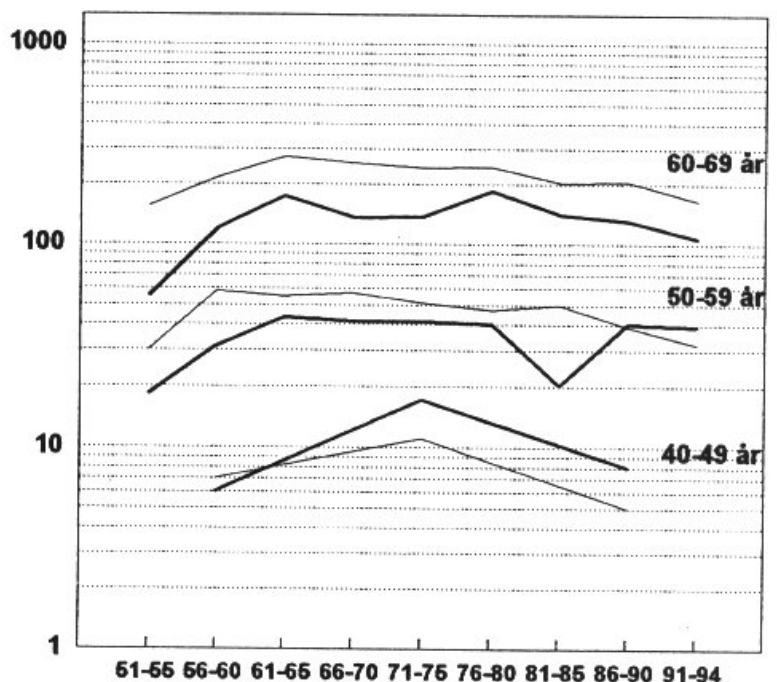

Øvrige Nord-Norge

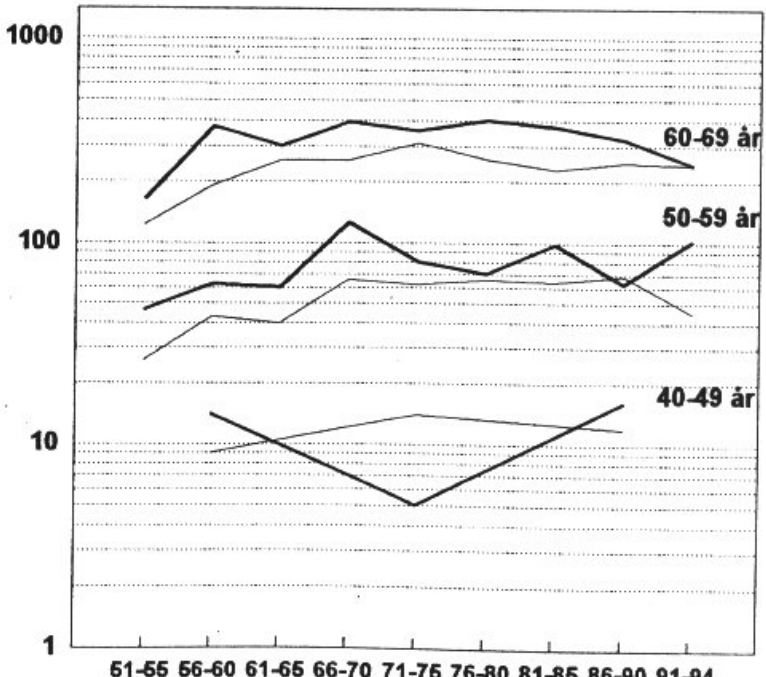



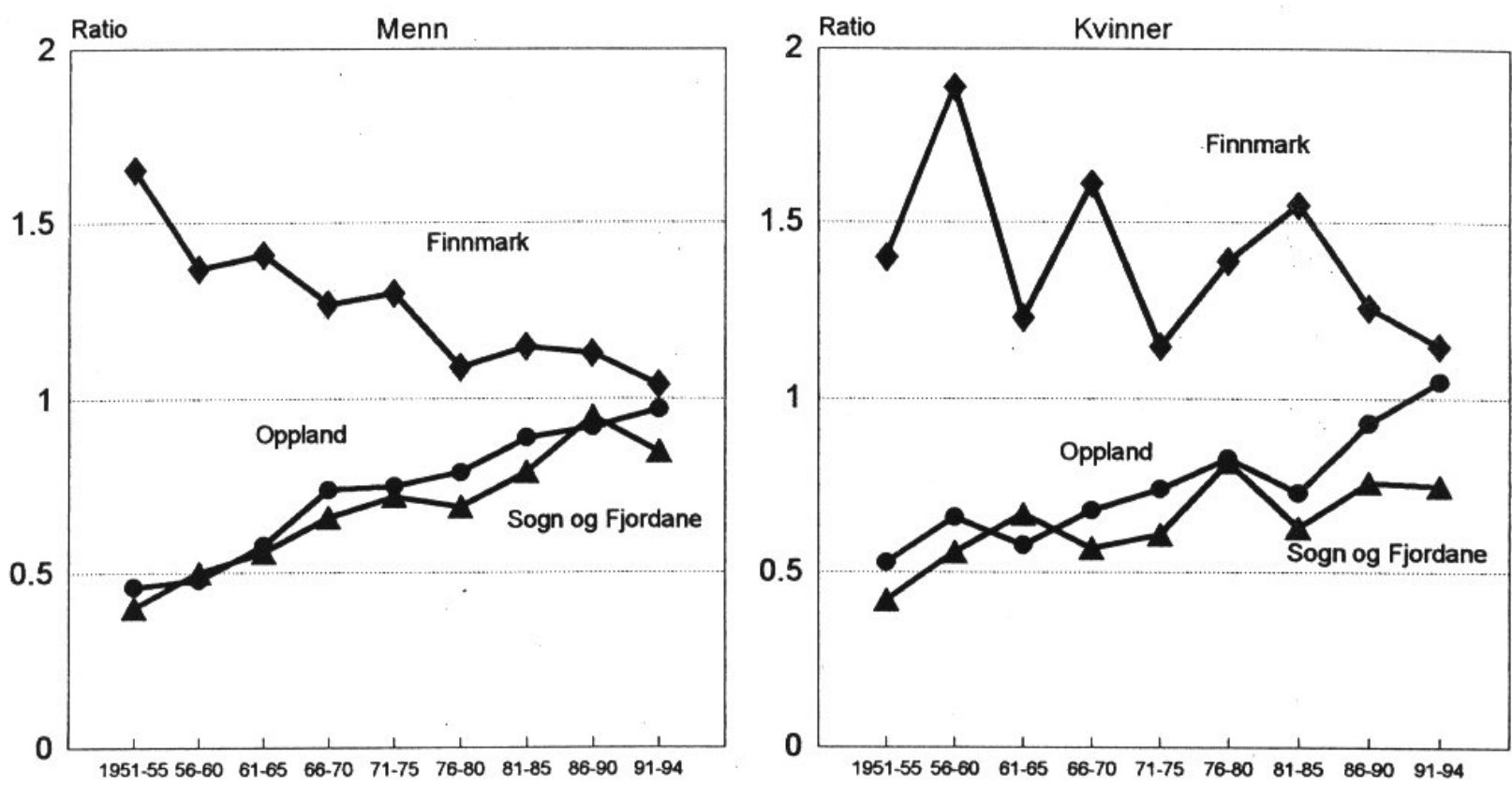

Figur 4. Forholdet (ratio) mellom dødeligheten i tre fylker og øvrige fylker i den tilhørende helseregionen. Alder 40-69 år, kombinert med Mantel-Haenszel estimatoren.
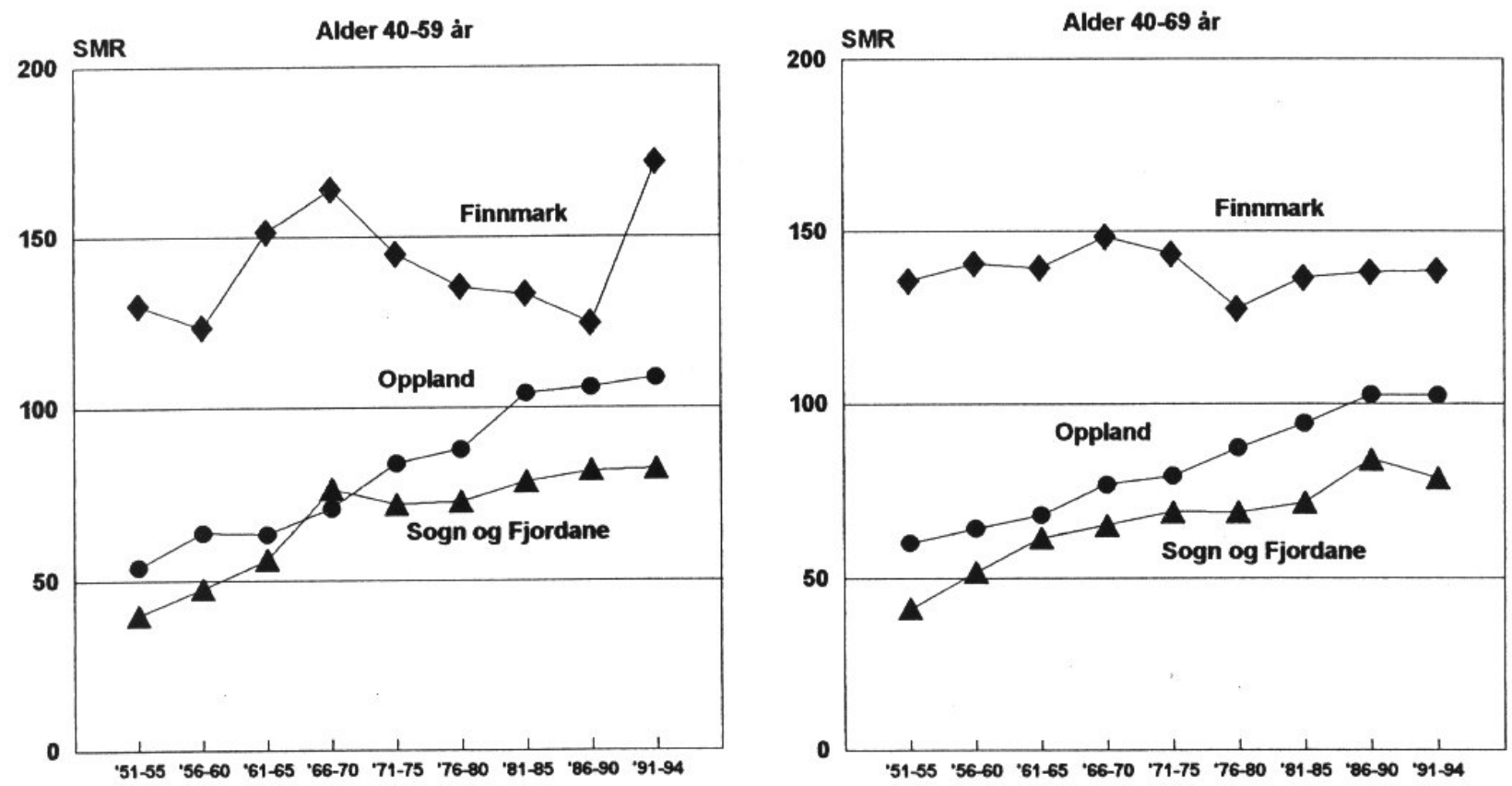

Figur 5. Standardisert mortalitets ratio (SMR). Menn og kvinner.

\section{Kjønnsforskjeller}

Den svakere relative nedgang for kvinner enn for menn fra 1971-75 kan tyde på at risikomønsteret har utviklet seg noe forskjellig i de to kjønn. Endringene i kolesterol og blodtrykk har ikke endret seg nevneverdig forskjellig i de to kjønn. I og med at sammenhengen mellom de tre viktige risikofaktorer og infarktdød er minst like sterk for kvinner som for menn (7), kan forskjellen i røykevaner bidra til å forklare forskjellen i den relative nedgangen i dødelighet hos kvinner og menn. Hvis kvinnene opprettholder en høyere røykeprevalens enn menn, og de øvrige risikofaktorer utvikler seg likt, vil det kunne forventes at nedgangen $\mathrm{i}$ infarktdødelighet vil være svakere, og eventuelt stanse tidligere, hos kvinner. 
Røykevanene kan også være en medvirkende forklaring på at dødelighetsøkningen var sterkere hos menn enn hos kvinner mellom 1951-55 og 1971-75. Vi vet at røykevanene utviklet seg forskjellig, men vi har ikke data på landsbasis for de to andre risikofaktorene.

\section{Endringer i kolesterol og endringer $i$ dodelighet}

Det var noe overraskende ingen sammenheng mellom endring i kolesterol og endring i dødelighet på fylkesnivå. Den mest nærliggende forklaring er at endringen i kolesterol var lik i mange fylker (Konferer tabell 1 og 2 i (5)). Andre forklaringer kan være: 1) Ikke valide dødsdiagnoser, 2) Ikke valide kolesterolgjennomsnitt, 3) Heterogen utvikling mellom fylkene i andre risikofaktorer, 4) Samme tidsperioder for endring i dødelighet og i kolesterolnivå.

En måte å nærme seg spørsmålet om validitet på hadde vært å studere fordelingen av de medvirkende årsaker. Dette har vært gjort på landsbasis for perioden 1951-70 (8), men har ikke vært gjort på fylkesnivå. Videre kunne hyppigheten av plutselige dødsfall vært studert på fylkesnivå. Bak denne dødsårsak kan det skjule seg hjerteinfarkt $\mathrm{i}$ og med at den er sterkt relatert til kolesterol, i hvert fall for menn (2).

Det samme laboratoriet har vært brukt for kolesterolbestemmelsene. Lavere frammøte vil imidlertid kunne gi et skjevt kolesterolnivå. I de senere år er frammøteprosenten for menn falt under $70 \%$, i enkelte fylker har den vært under $60 \%$. Videre er det ikke sikkert at kolesterolnivået $\mathrm{i}$ fylkene, og endringer $\mathrm{i}$ dette blant 40-42 åringer, er representativt for en bredere aldersgruppe.

Krüger har studert hvorvidt endringer i befolkningsgjennomsnittet er valid som mål på endring $i$ risiko i befolkningen (9). I nordvestre del av Oppland fylke var det i perioden 1966-70 til 1981-85 en dramatisk økning i dødeligheten av ischemisk hjertesykdom. Denne var ledsaget av en reduksjon i de viktigste risikofaktorene. Det ble funnet at endringer i kolesterolgjennomsnitt reflekterte endringer i hele kolesterolfordelingen. Endringene var også homogene i by- og landregioner. Det ble konkludert med at gjennomsnittet var et relevant komparativt mål i den studien.

I Seven countries studien fant man at endringen $i$ koronardødeligheten i prosent mellom 5 og 25 år var sterkt korrelert med endringer i kolesterol i løpet av de 10 første år i studien $(\mathrm{r}=0,67)(10)$. Det var videre slik at denne sammenhengen var sterkere hvis utgangsnivået for kolesterol var lavt. Det kan ut fra dette forventes en sterkere sammenheng mellom endringer $\mathrm{i}$ kolesterol og dødelighet når dødelighetsendringene er over en lengre periode som i vesentlig grad etterfølger perioden for kolesterolendringene. Hvorvidt disse delta-korrelasjoner vil være avhengig av utgangsnivået for kolesterol gjenstår også å se.

\section{Dodeligheten i Finnmark, Sogn og Fjordane og Oppland i forhold til de tilhorende helseregioner og Norge}

Det var ingen synlig effekt av hjerte-karundersøkelsene på dødelighetsutviklingen i de tre fylker. Analysen har neppe vært sensitiv nok til å oppdage små utslag. Både aldersgruppene og tidsperiodene er brede. En god design ville vært å gjøre en oppfølging av de som ble innkalt $i$ de tre fylker og en oppfølging fra samme tidspunkt av personer i samme alder, f.eks. fra de tilhørende helseregioner. En slik analyse har vært diskutert, men ble frafalt (11). En lik analyse som den i figur 5 ble gjort for hvert enkelt år i perioden 1969 til 1986 og det var ingen synlig effekt av hjertekarundersøkelsene (11).

Validiteten av dødsdiagnosene kan ha vært en forstyrrende faktor. Det kan tenkes at kjennskap til risikofaktorene har påvirket diagnosesettingen. Videre kan flyttinger ha påvirket dødelighetsmønsteret ved at personer med høy eller lav risiko har flyttet inn og ut av fylker.

\section{KONKLUSJON}

Over en 40 års periode har det vært samme tendens $i$ endringene av dødeligheten av hjerteinfarkt i samtlige fylker. Imidlertid har størrelsen på endringene variert mellom fylkene, slik at rangeringen fylkene imellom har endret seg. Den prosentvise økningen i første halvdel og den prosentvise nedgangen i dødeligheten i siste halvdel av perioden var klart svakere for kvinner enn menn. Det var ingen synlig forskjell i dødelighetstrender over tid i de tre hjerte-karfylker, sammenlignet både med landet og med de respektive helseregioner.

\section{REFERANSER}

1. Sosial- og helsedepartementet. Folkehelserapporten. Oslo: Sosial-og helsedepartementet, 1996.

2. Tverdal A. A mortality follow-up of persons invited to a cardiovascular disease study in five areas in Norway. Oslo: National Health Screening Service, 1989.

3. Bjartveit K, Wøien G. Risikofaktorer for hjerte-karsykdom i Norge. Resultater fra undersøkelser i 18 fylker. Oslo: Statens helseundersøkelser, 1997.

4. Healy MJR. GLIM: An Introduction. New York: Oxford, 1988. 
5. Wøien G, Øyen O, Graff-Iversen S. 22 år med hjerte-og karundersøkelser i norske fylker. Bør vi være tilfreds med den utviklingen som risikofaktorene har hatt? Norsk Epidemiologi 1997; 7 (2): 255-66.

6. Rothman K, Greenland S. Modern epidemiology. Second Edition. Philadelphia: Lippincott-Raven, 1998.

7. Stensvold I, Tverdal A, Urdal P, Graff-Iversen S. Non-fasting serum triglyceride concentration and mortality from coronary heart disease and any cause in middle aged Norwegian women. BMJ 1993; 307: 1318-22.

8. Statistisk sentralbyrå. Dødelighetsutvikling og dødsårsaksmønster 1951-1970. Oslo: Statistisk sentralbyrå, 1974.

9. Krüger Ø. Aggregate disease risk-factor data: is the population mean a valid parameter? The example of serum cholesterol in Oppland county, Norway. Norsk Geografisk Tidsskrift 1990; 44: 221-226.

10. Menotti A, Blackburn H, Kromhout D, et al. Changes in population cholesterol levels and coronary heart disease deaths in seven countries. Eur Heart J 1997; 18: 566-571.

11. National Health Screening Service, Health Services of Finnmark, Sogn og Fjordane and Oppland Counties, Ullevål Hospital, Central Laboratory, Oslo. The cardiovascular disease study in Norwegian counties. Results from second screening. Oslo: National Health Screening Service, 1988. 


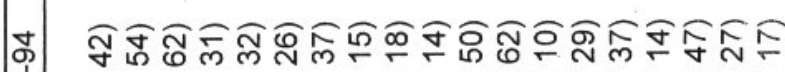

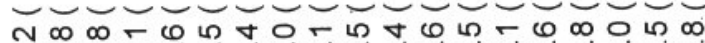

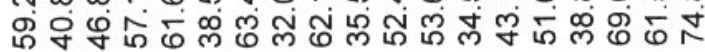

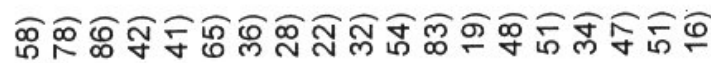

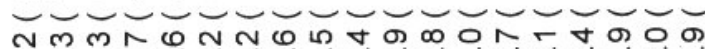

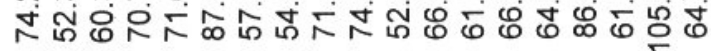

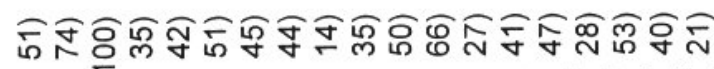

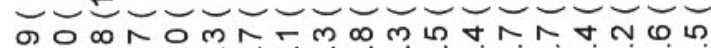
๓

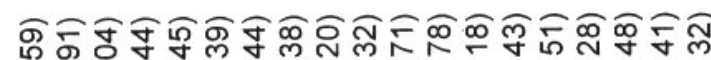
- Non m ดั

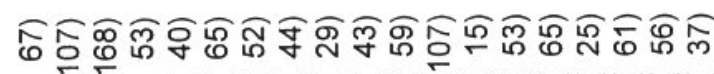
O

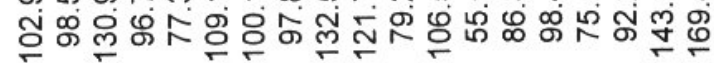

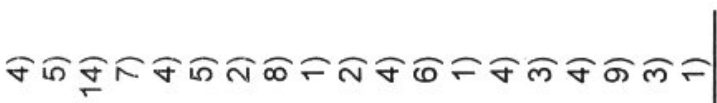
๓ ம

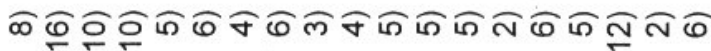
ம 으유

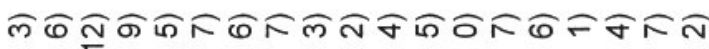
$\smile \smile \smile \smile \smile \smile \smile \smile \smile \smile \smile \smile \smile \smile \smile \smile \smile$

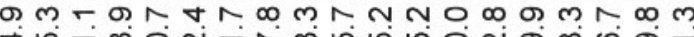
ช

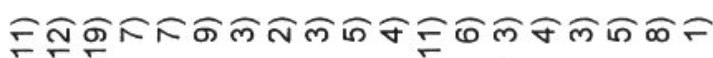

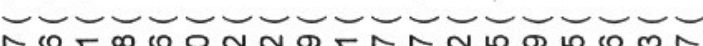
œ

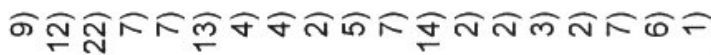
ल 픔

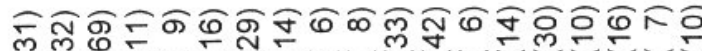

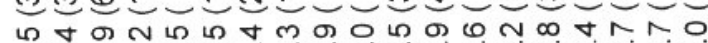

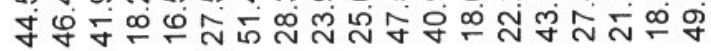

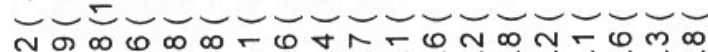

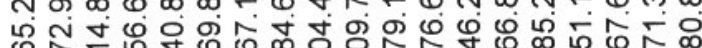

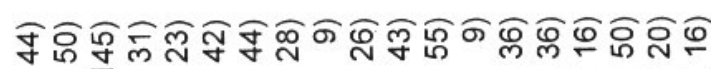
एऍ

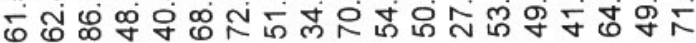

满

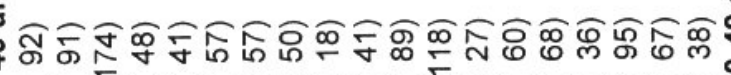

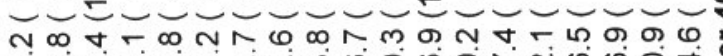

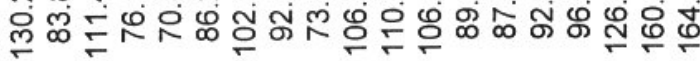

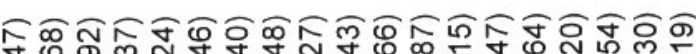

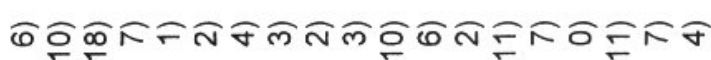
$\smile \smile \smile \smile \smile \smile \smile \smile \smile \smile \smile \smile \smile \smile \smile \smile \smile$

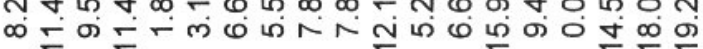

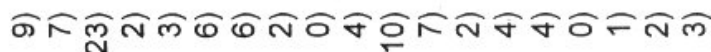
ANN 음

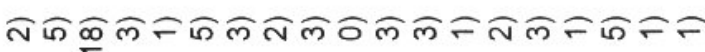
U一 d ก

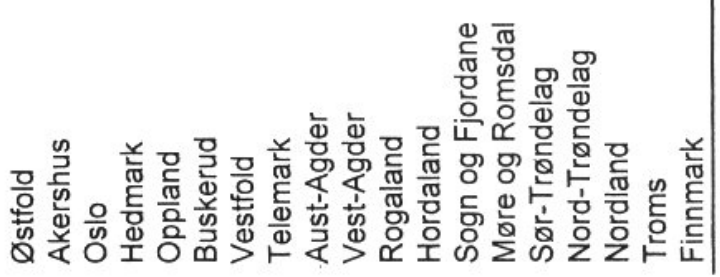




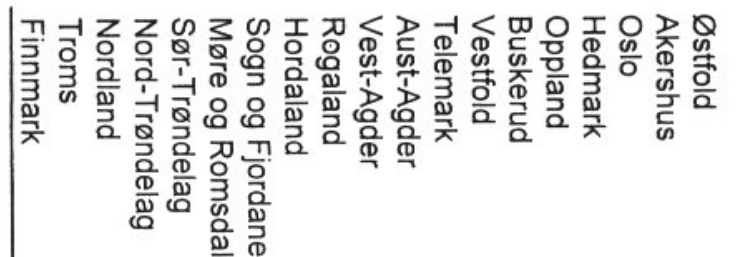

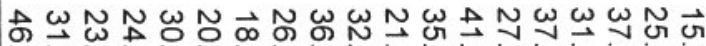

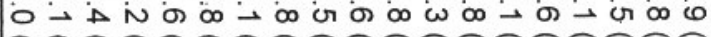

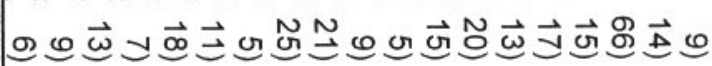

P

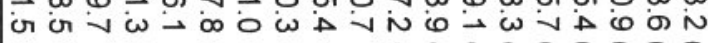

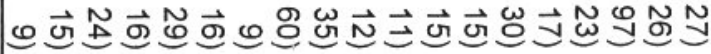

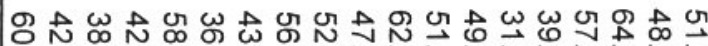
$\rightarrow N \rightarrow 0 \omega \rightarrow$ or $N \rightarrow N \omega \omega \omega \omega$.

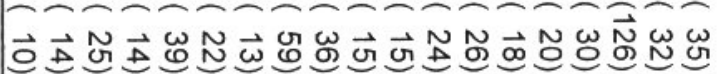
(

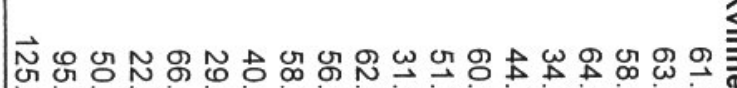

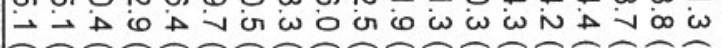

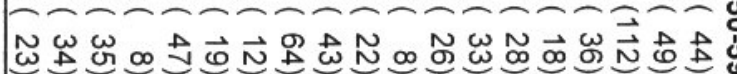

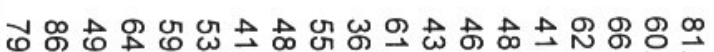
$V \rightarrow N \infty \omega$ G

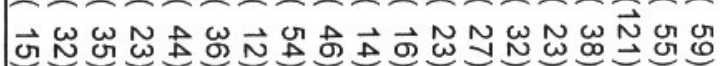

రำ ભ ल

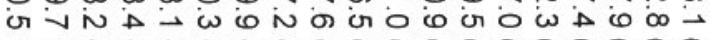

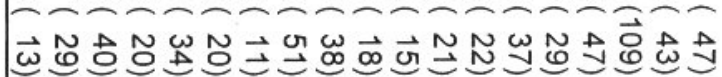

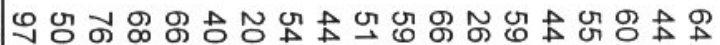

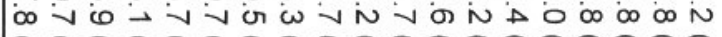

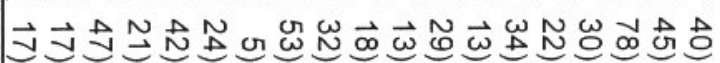

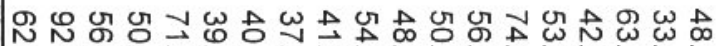

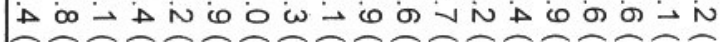

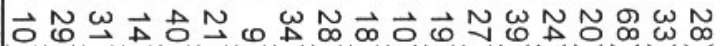

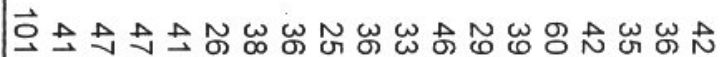

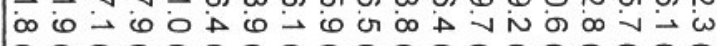

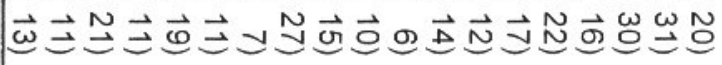

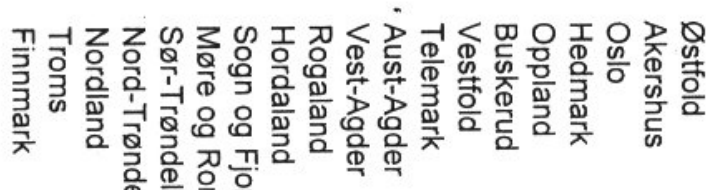

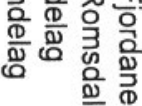

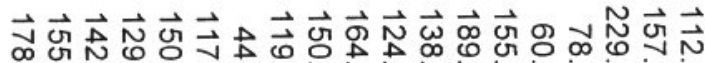

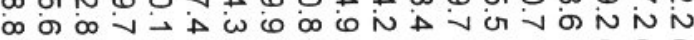
공

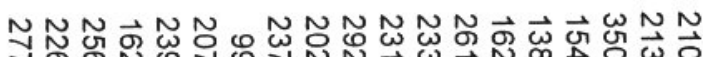
$\omega \infty$ i $\omega$ N 

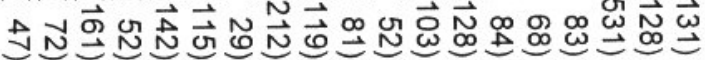

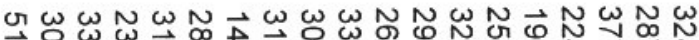

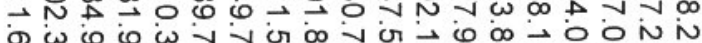

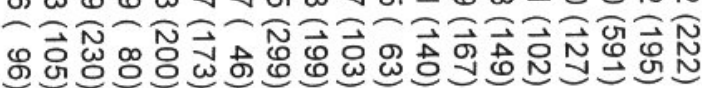
要

or $\Delta \omega N \omega \omega N \omega \omega N N \omega \omega \omega N N \omega N \omega$ G I

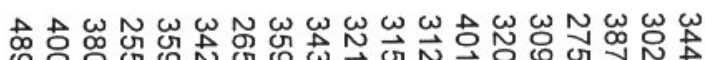

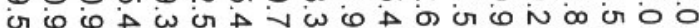

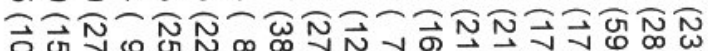

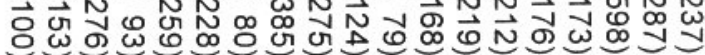

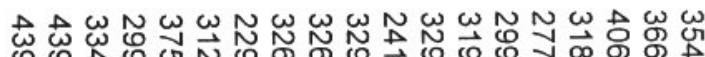

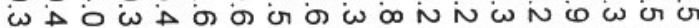

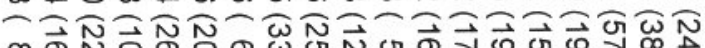

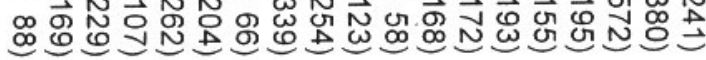

$\Delta \omega \omega \omega \omega N N \omega N N \omega \omega N \omega \omega \omega \omega N \omega$

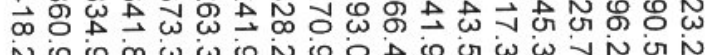

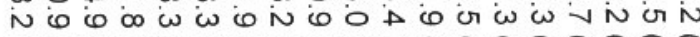

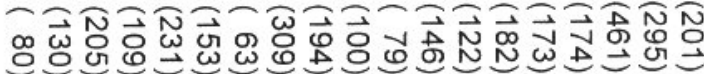

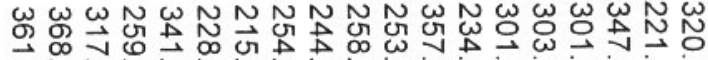

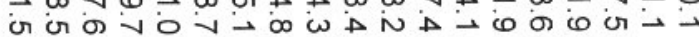

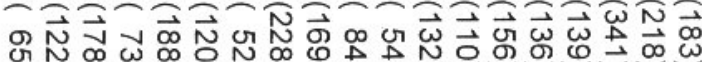

N N N

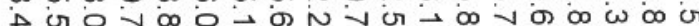
-

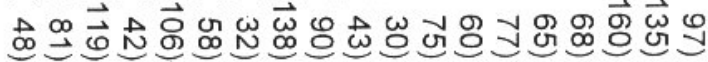


ลิำดำสำ 던

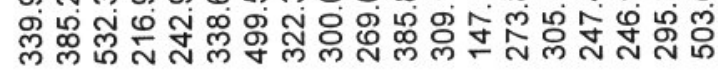

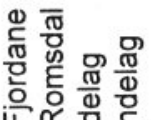

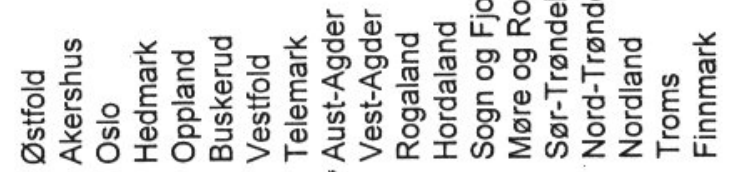

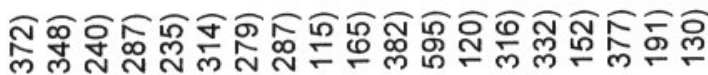

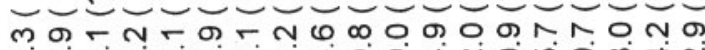

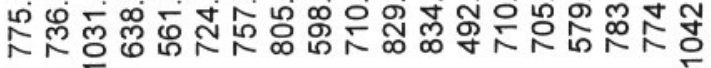

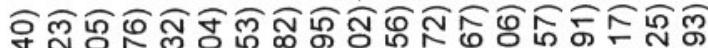

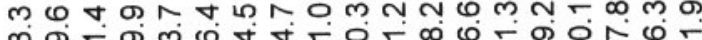

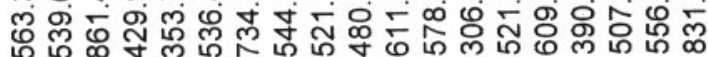

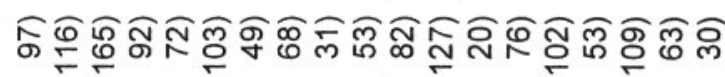

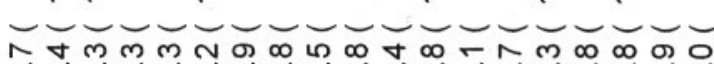

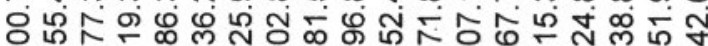

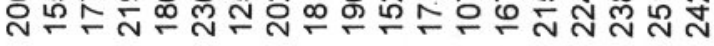

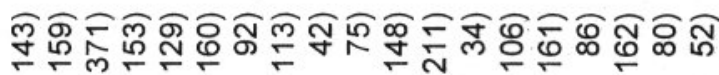

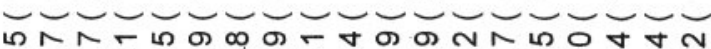

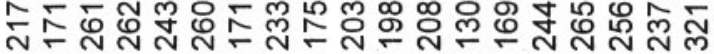

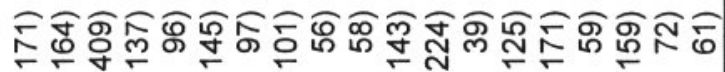

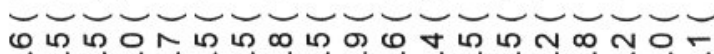

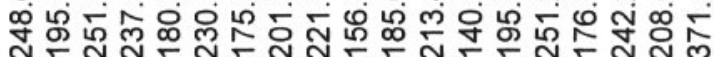

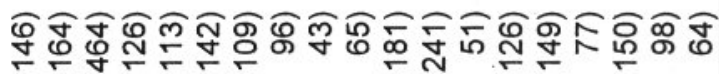

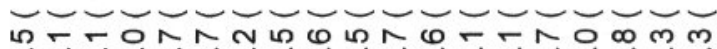

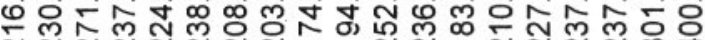
ลNลN N

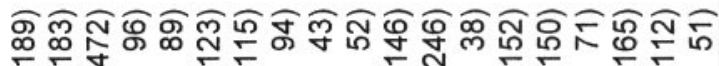

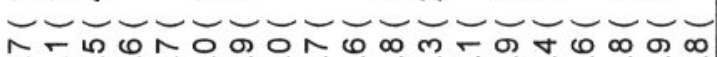

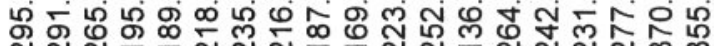

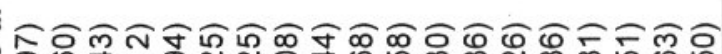

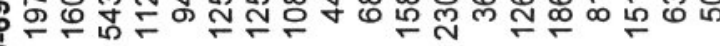

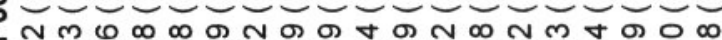

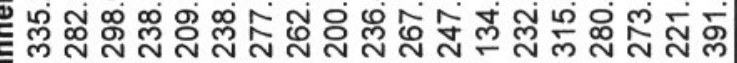
要

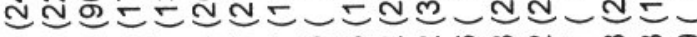

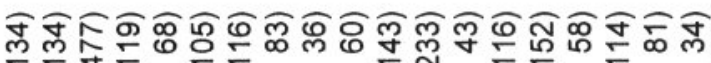

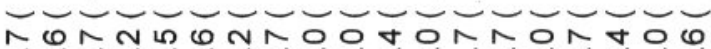

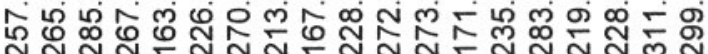

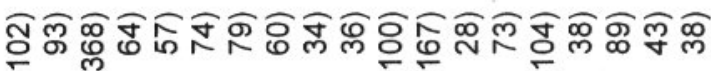
r m mor

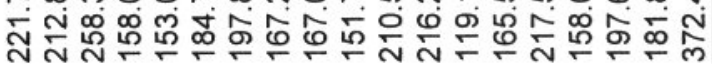

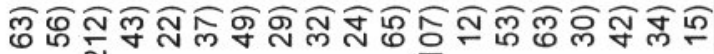
ก

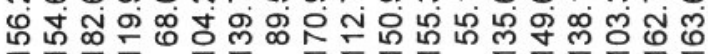

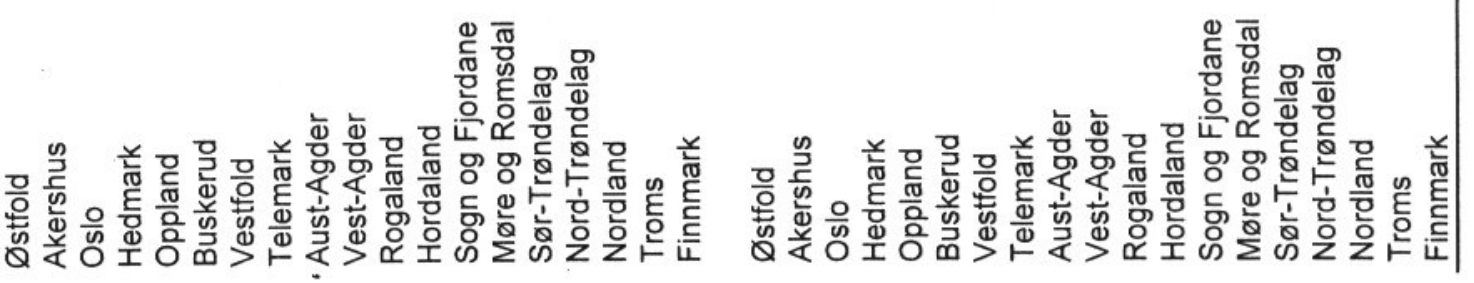

